\title{
Strengthening participatory local governance for improved service delivery: The case of Khayelitsha
}

\section{Authors:}

Kanyalitsoe Malemane ${ }^{1}$ (D)

Danielle Nel-Sanders ${ }^{1}$ (D)

\section{Affiliations:}

${ }^{1}$ School of Public Management, Governance and Public Policy, College of Business and Economics, University of Johannesburg, Johannesburg, South Africa

Corresponding author: Kanyalitsoe Malemane, kanyamalemane@gmail.com

Dates:

Received: 28 Sept. 2020

Accepted: 11 June 2021

Published: 23 Aug. 2021

How to cite this article: Malemane, K. \& Nel-Sanders, D., 2021, 'Strengthening participatory local governance for improved service delivery: The case of Khayelitsha', Africa's Public Service Delivery and Performance Review 9(1), a500. https://doi.org/ 10.4102/apsdpr.v9i1.500

\section{Copyright:}

C 2021. The Authors. Licensee: AOSIS. This work is licensed under the Creative Commons Attribution License.

\section{Read online:}

Background: The need for participatory local governance is urgent, especially in the developing countries of the Global South, where local citizens have been disenfranchised for many years. The common practice in developing countries is that public policies, programmes and projects are designed by public officials and external 'experts' on behalf of local communities. Externally designed public interventions may fail to meet the needs of communities.

Aim: This article seeks to explore the mechanisms to strengthen participatory local governance for improved service delivery in South Africa. Specifically the article examines the mechanisms that could be put in place to enhance participatory local governance for improved service delivery in Khayelitsha.

Methods: The article is based on a qualitative case study conducted in Khayelitsha, an informal settlement in Cape Town. A combination of primary data collection instruments and secondary data collection instruments to gather qualitative data was employed.

Results: Participatory local governance enhances the support and ownership of public interventions by local communities. Without community participation in local governance, public policies, programmes and projects are bound to fail due to lack of local support and ownership. In instances where local communities or their representatives are excluded from decision-making processes, a structural vacuum is created. Often the community were not consulted for their input, hence the failure of many public interventions.

Conclusion: A number of mechanisms can help promote and strengthen public participation in local governance, including: the creation of an enabling environment for citizen participation; building strong social capital; promoting collaborative engagements; increase capacity in the local community; holding regular public meetings and building strong ward committees.

Keywords: service delivery; local governance; public participation; participatory local governance; civil society organisations; collaborative engagement.

\section{Introduction}

The advent of democracy in South Africa in 1994 ushered in a new era for South African municipalities and redefined the role of local government. The transformation of local government was aimed at making municipalities pro-poor, developmental, inclusive and democratic. The transformation was imbedded in a host of legislative instruments and policy documents, key amongst them being the Constitution of the Republic of South Africa 1996; the Local Government: Municipal Structures Act, No.117 of 1998; the Local Government: Municipal Systems Act, No. 32 of 2000; the Public Finance Management Act 1 of 1999; the White Paper on Local Government of 1998 and the White Paper on the Transformation of the Public Service (WPTPS) (Batho Pele White Paper) of 1997. These legislative instruments and policies were aimed at transforming South African municipalities into viable and effective entities. This article provides an overview of the meaning and implications of participatory local governance.

The mandate of local government in South Africa is captured in section 152(1) of the Constitution of the Republic of South Africa, 1996. According to section 152(1) of the Constitution the 'objects of local government are:

- to provide democratic and accountable government for local communities

- to ensure the provision of services to communities in a sustainable manner

- to promote social and economic development

- to promote a safe and healthy environment 
- to encourage the involvement of communities and community organisations in the matters of local government' (RSA 1996).

To achieve their constitutional mandate of local social, economic and environmental sustainability, it is imperative for local authorities to demonstrate good governance. Municipalities have a further mandate to create an enabling environment that allows citizens to participate in decision-making processes on matters of local governance and public interest. Hillard and Wissink (2000:97). Concurred that 'South African local authorities must become catalysts of growth and development; otherwise they might be unable to justify their continued existence in the local sphere'. Van der Waldt (2017:97) agreed that the local sphere of government is ideally placed to address local needs and concerns.

The article seeks to explore the strategies to strengthen public participation in local governance for improved service delivery in Khayelitsha. Firstly, this article will discuss the problem statement, the objectives of the study and the conceptual framework of the study. The article then discusses the findings and recommendations.

\section{Problem statement}

Despite the legislative mechanisms put in place to promote and guide public participation in local governance, participatory local governance in South Africa remains problematic. Lack of public participation in matters of local governance manifests itself in the many problems faced by municipalities. Ramjee and Van Donk (2011 in Good Governance Learning Network 2011:10) asserted that 'local government in South Africa is faced with problems of low fiscal reserves, poor management, service delivery backlogs and increasing community protests'. The grim picture facing South African municipalities is further captured by Mchunu, Theron and Mubangizi (2016 in Theron \& Mchunu 2016:177), who mentioned that the current structure of public participation provided for by local government legislation is largely inadequate for facilitating meaningful and inclusive expressions of voice, particularly for poor and marginalised grassroots beneficiaries'. Poor communities remain sidelined in decision-making on matters of local governance. Department of Cooperative Governance and Traditional Affairs (1998: 23) argued that 'millions of our people live in dire poverty, isolated from services and opportunities'.

The imperative of participatory local governance cannot be overemphasised. Without public participation in decisionmaking processes on matters of public interest, public policies, programmes and projects may fail to meet the felt needs of local communities. Poor public participation also leads to lack of support for public programmes and interventions by the intended beneficiaries. Cloete (2018 in Cloete et al. 2018:143) concurred that participation is essential to legitimise the decisions and actions of the government and to inform the government of public views and perceptions. Lack of public participation has also been shown as a source of violent service delivery protests that are prevalent in South African municipalities. In this regard, Siddle and Koelble (2012:9) postulated that 'community protests against poor service delivery have become a constant feature of South African life, starting in 2004 and continuing to date'. The local communities resort to violent protests as a mechanism to express their disillusionment and dissatisfaction when they face unfulfilled promises, deteriorating living standards and public officials who lack political will to serve the interests of the poor.

The informal township of Khayelitsha, like other poor urban communities in South Africa, is faced with problems associated with poor public participation in matters of local governance. Khayelitsha has been bedevilled by poor basic services delivery and the problem of violent service delivery protests. It is against this background that this article seeks to examine the mechanisms that could be put in place to enhance participatory local governance for improved service delivery in Khayelitsha.

This study seeks to address the following primary research question: What are the mechanisms for strengthening participatory local governance for improved service delivery in Khayelitsha? In order to address this question, the research is guided by the following objectives:

- to explore the conceptual framework of participatory local governance for improved service delivery in Khayelitsha

- to examine the regulatory and policy contexts of participatory local governance in South Africa

- to determine the key role players in local governance in Khayelitsha

- to explore the benefits derived from citizen participation in local governance in Khayelitsha

- to examine the contribution of citizen participation to good local governance in Khayelitsha

- to suggest proposals on how participatory local governance could be strengthened for improved service delivery in Khayelitsha.

\section{Conceptual clarification and framework}

A conceptual framework is critical to place a study into context and to aid communication of the main concepts specific to the study to various audiences. Neuman (2011:205) posited that 'as researchers gather and analyse qualitative data, they develop new concepts, formulate definitions for major constructs, and consider relationships amongst them'. According to Babbie (2016:128), conceptualisation can be seen as 'the process through which we specify what we mean when we use particular terms in research'.

Conceptualisation, in relation to this article, is critical to help the researcher unpack the key concepts related to the topic under investigation, operationalise the concepts and communicate the concepts and theories to the audience of the article. Without a clear and detailed conceptual framework, it becomes difficult for the audience to comprehend the 
article. Concepts relevant to this research are clarified in the following sections.

\section{Conceptualising 'local governance'}

In its simplest terms, local governance can be seen as referring to how power is exercised, shared and checked through mechanisms of participation, accountability, transparency, rule of law and a responsive public sector at the local level of government. The United Nations Development Programme (UNDP 2009:173) defined local governance as 'a set of institutions, mechanisms and processes through which citizens can express their interests and needs, mediate differences and exercise their rights and obligations at the local level'. Local governance encompasses a system of values and policies that govern behaviour at the local level. Local governance entails a system of interactions and relationships between public officials and citizens at the local level of government. Governance at the local level is also concerned with the provision of basic services to meet the needs of local communities. In general, it is on 'the local levels of governance where sustainable development programmes are executed via service delivery projects and where people acutely experience the level of goodness of governance' (Van der Waldt 2017:97).

\section{Conceptualising 'good local governance'}

A discussion of local governance is incomplete without mention of the concept 'good local governance'. In its simplest terms, good local governance can be seen as referring to the desired standards of practices at the local level of government. Good local governance entails mechanisms and processes of local governance that promote equality, local democracy, citizen participation and inclusive decision-making processes.

According to the UNDP (2009:174), 'good local governance systems require engaged and empowered local communities capable of articulating their needs and participating in setting priorities, making decisions and monitoring and implementing programmes'. In short, good local governance is achieved when public officials create an enabling environment that allows citizens to participate in decisionmaking processes on matters that affect their lives. Good local governance creates opportunities for citizen empowerment and participation in public affairs. According to the UNDP (2009:174) 'good local governance is characterised by the following building blocks:

- citizen participation

- partnerships amongst key actors

- capacity of local actors

- multiple flows of information

- institutions of accountability

- pro-poor orientation'.

\section{Conceptualising 'public participation'}

'Participation' and 'public participation' are popular concepts in the social sciences. According to Theron and Mchunu (2014 in Davids \& Theron 2014:113), public participation has become a buzzword and a 'feel good' concept. Citizen participation in governance has been widely accepted as one of the key elements of good governance. However, Cooke and Kothari (2001:1) cautioned against the use of the concept of 'participation' in a misleading fashion in what they term the 'new tyranny' in development work. According to Cooke and Kothari (2001:1), development practitioners should guard against looking at participation as a panacea for all development problems. Public participation can be defined as the involvement of citizens in decision-making processes on matters that affect their day-to-day living. Andre et al. (2006) defined public participation as:

[T] he involvement of individuals and groups that are positively or negatively affected by a proposed intervention (e.g. a project, a programme, a plan, a policy) subject to a decision-making process or are interested in it. (p. 1)

In this regard, public participation entails involving the local community in the planning, implementation, monitoring and evaluation of a public policy, programme or project.

\section{Conceptualising 'participatory local governance'}

Participatory local governance, also known as 'democratic local governance', entails the involvement of local citizens in decision-making processes in the affairs of a city or town. It involves the creation of an enabling environment that allows local citizens and their organisations, to participate in decision making on matters of local governance. In this regard, Van der Waldt (2014a in Van der Waldt 2014) mentioned that:

[T] he local sphere is an arena where citizens and civil organisations, such as NGOs, CBOs, or ratepayers' associations, can participate in decision making with regard to the environments in which they live, and exercise and extend their democratic rights. (p. 53)

\section{Models of public participation in local governance}

Various models have been put forward by social science practitioners in an effort to describe the levels of public

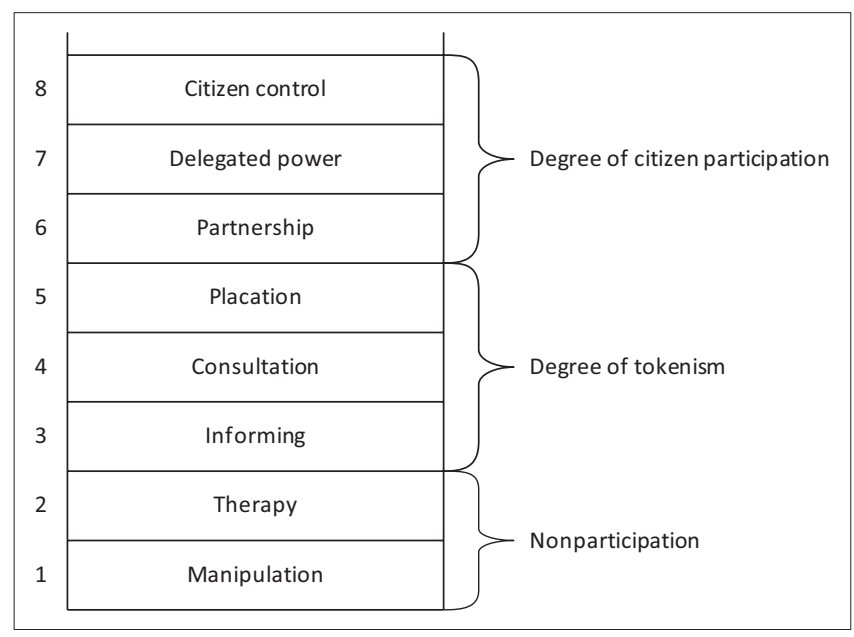

Source: Arnstein, S.R., 1969, 'A ladder of citizen participation', Journal of the American Planning Association 35(4), 216-224.

FIGURE 1: Arnstein's ladder of citizen participation. 
participation in decision-making processes. The models describe the degree of public participation and control over decision-making processes in community development initiatives, programmes and projects. The models are also applicable to describe public participation in matters of local governance. For the purposes of this study, Arnstein's (1969) Ladder of Citizen Participation was adopted and described here (see Figure 1).

Arnstein's (1969) model is used to illustrate citizen participation in decision-making processes. The typology gives eight levels or rungs on a ladder that depict citizen participation, control and influence in decision making.

\section{Manipulation}

Manipulation is one of the two bottom rungs of the ladder. Manipulation describes a distorted form of participation by citizens in decision-making processes. Citizens at this level are powerless and have no influence over public interventions. Public officials and external experts decide the problems, alternatives and solutions on behalf of the beneficiaries. In the name of public participation, 'people are placed on rubberstamp advisory committees or advisory boards for the express purpose of "educating" them or engineering their support' (Arnstein 1969:218). The local community has no significant impact on the decision-making process. Decisions are made by the powerful groups on behalf of citizens.

\section{Therapy}

Like manipulation, therapy depicts lack of control and influence by citizens. The objective in both manipulation and therapy 'is not to enable people to participate in planning or conducting programmes, but to enable powerholders to "educate" or "cure" the participants' (Arnstein 1969:217). No attempts are made to transfer control and influence to the local community over the design of policies, programmes and projects. As a result, local communities have less impact and control on envisaged public interventions.

\section{Informing}

This is one of the three rungs that represent tokenism. Citizen participation is used as a token to gain support for public policies, programmes and projects. Citizen input is not implemented. According to Arnstein (1969:217) at the levels of informing and consultation, citizens lack the power to ensure that their views are heeded by the powerful. Public officials and external experts wield more control and influence than the local community. The local community is not yet given full control to make independent decisions.

\section{Consultation}

Like informing, consultation is used as a token for public support. When powerholders restrict the input of citizens' ideas solely to the level of consultation, participation remains just a window-dressing ritual (Arnstein 1969:219). The most common methods used for citizen consultation include attitude surveys, neighbourhood meetings and public hearings. At the level of consultation, people are perceived as statistical abstractions and participation is measured in terms of the number of people who attended the meeting and answered the survey questionnaire (Arnstein 1969:219). No serious attempts are made to give feedback and to transfer power to the local citizens.

\section{Placation}

Placation is the higher level of tokenism. At this level, public officials create conditions that allow for citizen participation. However, the powerful retain the right to decide on behalf of citizens. Citizens still lack the power to control and influence decisions.

\section{Partnership}

Partnership is the beginning of genuine citizen participation and influence over public policies, programmes and projects. Local citizens enter into partnership with public officials that give them control and influence over public interventions.

\section{Delegated power}

Delegated power gives local communities the power to make decisions on matters that affect their lives. This approach resonates with ideas put forward by Swanepoel and De Beer (2011:76) who recommended that 'local knowledge and skills should be used through participation' to solve local problems. The local community, through their representatives and community structures, is actively involved in the design, planning, implementation and evaluation of public policies, programmes and projects.

\section{Citizen control}

Citizen control is the highest rung on the ladder. Citizens have full control and influence over decision- making processes. The community takes full responsibility for and control over projects and processes they have embarked upon (Swanepoel \& De Beer 2011:77). Public officials and external experts seek the advice of local citizens. Citizens have the power to decide public interventions that are appropriate to meet their needs and local circumstances. Citizens actively participate in the entire programme or project process - designing, planning, implementation, monitoring and evaluation. The role of public officials is to implement, together with the local community, what people decided.

\section{Research methodology}

The study employs a qualitative approach. According to Babbie and Mouton (2001:270), 'qualitative research is conducted in the natural setting of social actors and the primary aim is in-depth (thick) descriptions and understanding of actions and events'. Qualitative research is based on the interpretation of the subjective meanings research participants attach to their lived experiences. Unlike the quantitative approach that produces numerical data, the 
qualitative approach produces non-statistical results. The qualitative approach enables the researcher to gather in-depth descriptions of a social phenomenon under investigation.

\section{Case study design}

This article is based on the results of a single case study of the Development Action Group (DAG), a non-governmental organisation (NGO) that runs developmental programmes in Khayelitsha. A single case study focusses on a single area of concern, which the researcher then investigates in a bounded context. Yin (2012:7) posited that 'if you were limited to a single organisation, you would have an embedded, singlecase study'. Development Action Group's programmes are aimed at enhancing participatory local governance in Khayelitsha. The flagship programmes include the People's Housing Process (PHP), Enhanced People's Housing Process (EPHP), neighbourhood development and local leadership training. The programmes enable local citizens in Khayelitsha to be involved in their development in partnership with Ward Councillors and DAG.

\section{Data collection methods and analysis of the data}

The researcher employed a combination of primary data collection instruments and secondary data collection instruments to gather qualitative data.

\section{Primary data collection}

Primary data were collected using semi-structured interviews and informal observation at the research site. Face-to-face and telephonic interviews were conducted with members of the local community in Khayelitsha, Ward Councillors in Khayelitsha and DAG officials and beneficiaries from DAG's programmes. Creswell (2009:181) asserted that in 'qualitative interviews, the researcher conducts face-to-face interviews with participants, interviews participants by telephone or engages in focus group interviews'. Informal observation, on the other hand, entailed the researcher visiting the research site for a day to observe the activities at the site. In this regard, Neuman (2011:426) mentioned that a field researcher 'observes ordinary events and everyday activities as they happen in natural settings, in addition to unusual occurrences'. The researcher wrote down notes during the observation.

To analyse primary data, the researcher employed 'thematic analysis'. A theme is a recurring or patterned idea that relates to the research question and the responses from the research participants. The researcher established core themes from the interview questions and recurring concepts from participants' responses. The core themes extracted were used as focal points to analyse the research data.

\section{Secondary data collection}

Secondary data were collected from secondary sources to enhance the scientific vigour of the research. These data were also used to substantiate primary data. The secondary sources used as a source of secondary data included the internet (online) sources, DAG's website, academic textbooks, government legislation, unpublished master's and doctoral theses and peer-reviewed journals. Secondary data were analysed by means of unobtrusive techniques. Unobtrusive research techniques involve the collection of data without interfering with the sources of the data. Auriacombe (2016:6) concurred that unobtrusive techniques ensure that there is no direct interaction between researchers and respondents. When using unobtrusive techniques, the researcher does not interfere with or influence responses from the participants. Two unobtrusive techniques were utilised: conceptual analysis and documentary analysis. Conceptual analysis involved extracting concepts from the collected data in order to interpret, explain and extrapolate meaning from the data. Documentary analysis, on the other hand, entailed the systematic study of documented information in order to extract meaning from the documents.

\section{Research sample}

The researcher employed purposeful sampling techniques to select participants for the research. Purposive sampling entails selecting research participants on the basis of their knowledge and experience about the subject under investigation. According to Creswell and Creswell (2018:148), purposeful sampling is 'a type of non-probability sampling that enables the researcher to intentionally sample a group of people who can best inform the researcher about the research problem under investigation'. It is important to note, however, that the goal of this study was not to generalise the research results; hence a small sample is appropriate. According to Patton (2002:14), qualitative methods, unlike quantitative approaches, produce in-depth information about a smaller number of people and cases but reduce generalisability. This study was small-scale in nature and the researcher interviewed a limited number of participants. Time and cost constraints were also factors that limited the size of the sample. Table 1 provides an overview of the sample employed in this research.

\section{Key findings of the study}

The researcher employed key themes (thematic analysis) to help focus the discussion of the findings. Data from

\begin{tabular}{|c|c|c|c|}
\hline Participant & Pseudonym & Organisation & $\begin{array}{l}\text { Number of } \\
\text { participants }\end{array}$ \\
\hline Ward councillor & WC-1 & Sub-council 9 & 1 \\
\hline Ward councillor & WC-2 & Sub-council 10 & 2 \\
\hline Programme manager & PM & DAG & 1 \\
\hline $\begin{array}{l}\text { Programme beneficiary } \\
\text { (Housing programme) }\end{array}$ & PB-1H & DAG (sub-council 10) & 1 \\
\hline $\begin{array}{l}\text { Programme beneficiary } \\
\text { (Training programme) }\end{array}$ & PB-2T & DAG (sub-council 9) & 1 \\
\hline Local community member & LCM-1 & Sub-council 9 & 1 \\
\hline Local community member & LCM-2 & Sub-council 10 & 1 \\
\hline Total number of participants & - & - & 8 \\
\hline
\end{tabular}


secondary sources such as academic textbooks, peer reviewed journals and the internet were also used to support and substantiate primary data. The key findings of the study are discussed next.

\section{Key role players in local governance in Khayelitsha}

The theme is based on the research question: Who are the key role players in local governance in Khayelitsha? Local governance is an arena that consists of a diversity of actors. Research participants were able to identify the key role players in local governance in Khayelitsha such as the local community, Ward Councillors, the private sector (business) and civil society organisations (CSOs) such as NGOs, Trade Unions and community-based organisations (CBOs). Swanepoel and De Beer (2011:76) asserted that local government is not the only development role player in service delivery in local communities. Participants gave varied responses about the roles of ward councillors. Ward Councillors were seen as representing the government and acted as a link between the government and local communities. Participants mentioned that ward councillors were responsible for ensuring that citizens' concerns and needs were presented to the relevant government authorities. Ward councillors were also seen as being responsible for the provision of basic services to local citizens.

\section{Local government as a role player in local governance}

As the key actor in local governance, local government is responsible for the design, promotion and implementation of local policies in collaboration with other actors. Local government officials have a responsibility to render ethical leadership to ensure the achievement of sustainable economic and social development of the local community. Local government:

[C]an play an important role in bringing together the actors to build a common vision of how to respond to a locality's problems in a coordinated way in order to promote sustainable improvements to the quality of local people's lives. (UNDP 2009:173)

Bringing together the various role players in a coordinated manner to achieve local development is achieved through integrated development planning (IDP) processes. The introduction of the IDP system in 2001 required that all municipal councils develop strategies for community involvement (Skenjana \& Kimemia, in GGLN 2011:59).

\section{The local community as a role player in local governance}

The local community has a critical role to play in terms of their input in decision-making processes on matters of local governance. The local community plays an important role in development programme planning, implementation, monitoring and evaluation. According to the White Paper on Local Government (CoGTA 1998:33-34), municipalities require active participation by citizens on the following four levels:

- 'as voters, to ensure maximum democratic accountability of the elected political leadership for the policies they are empowered to promote

- as citizens, who express, via different stakeholder associations, their views before, during and after the policy development process in order to ensure that policies reflect community preferences as far as possible

- as consumers and end users, who expect value for money, affordable services and courteous and responsive services

- as organised partners, involved in the mobilisation of resources for development via for-profit organisations, businesses, NGOs and CBOs' (CoGTA 1998:33-34).

Public officials at the local level have a constitutional mandate to create an enabling environment that promotes the participation of local communities in decision-making processes on matters that affect their lives. Without the support, participation and ownership of local communities, public policies, programmes and projects are bound to fail. When development processes do not take the local structures into consideration, an institutional vacuum is created, with the result that efforts collapse as soon as benefactors start to withdraw structural support (Swanepoel \& De Beer 2011:76).

\section{Non-governmental organisations as a subset of civil society organisations}

As a subset of CSOs, NGOs create political spaces for the local community to participate in matters of local governance. Non-governmental organisations are mechanisms through which the voices and concerns of the local citizens are expressed as a collective. Writing on the role of NGOs in local governance, the World Bank (1989:54) mentioned, 'The aims should be to empower ordinary people to take charge of their lives, to make communities more responsible for their development and to make governments listen to their people'. Non-governmental organisations may therefore advocate for human rights, act as watchdogs to local government officials and participate in local service delivery through community development programmes and projects. However, participants argued that NGOs in Khayelitsha, such as DAG, were not visible enough to represent the interests of the poor masses in the community. Participants argued that without a vibrant NGO sector, their concerns were not taken seriously by government officials.

\section{Basic services provided by local government in Khayelitsha}

The theme was based on the question: What are the basic services provided by local government to citizens in Khayelitsha? Participants gave a comprehensive list of basic services provided by local government to citizens in Khayelitsha. The services mentioned included electricity, water and sanitation, refuse collection, internal roads and road maintenance and zoning and allocation of land and houses. Participants also mentioned public amenities such as recreational parks and 
libraries, healthcare facilities and job creation through the expanded public works programme (EPWP).

However, it is important to note that participants mentioned that service delivery in Khayelitsha was characterised by huge backlogs and unresponsive local government officials to the needs of local citizens. In this regard, Ramjee and Van Donk (GGLN 2011:11) asserted that local government has not responded to the needs repeatedly raised by communities during protests and has failed to communicate clearly as to why these needs have not been adequately addressed.

\section{The benefits of citizen participation in local governance in Khayelitsha}

The theme was based on the research question: Are there any benefits derived from citizen participation in local governance in Khayelitsha? Research participants argued that citizen participation was an imperative that could ensure that the voices and concerns of the local community, especially the poor masses, were brought to the attention of public officials. Furthermore, the participants mentioned that the community of Khayelitsha had a host of service delivery problems (such as lack of housing, service delivery backlogs, unemployment and crime) that could only be explained by the local people themselves and not the outsiders.

The UNCHS-Habitat (2000:11) asserted that 'civic engagement implies that living together is not a passive exercise: in cities, people must actively contribute to the common good'. Public participation ensures that public policies, programmes and projects are tailor-made to meet the actual, felt needs of the local communities. In this regard, Swanepoel and De Beer (2011:76) argued that 'local people have a much better understanding of their own circumstances, needs and aspirations than anybody on the outside'. Instead of waiting for public officials and external experts to design, plan and implement development interventions on their behalf, local communities should be actively involved in deciding the public interventions that are appropriate to meet their needs.

Research participants and secondary data confirmed that public participation improves the quality and sustainability of public interventions. Without the participation of local communities or their representatives, public policies and interventions are bound to be seen as 'exotic' and not meeting the needs of local citizens.

It is often argued that the participation of citizens in policy-making processes leads to qualitatively better policies and increased legitimacy of these policies in the eyes of the citizens (Van der Waldt 2014b in Van der Waldt 2014:7). Swanepoel and De Beer (2011:76) attested that local people are the experts on their own situation and this expertise should be used in solving local problems instead of relying on solutions from outsiders.
Participatory local governance enhances the support and ownership of public interventions by local communities. Research participants confirmed that without their participation in local governance, public policies, programmes and projects are bound to fail because of lack of local support and ownership. In instances where local communities or their representatives are excluded from decision-making processes, a structural vacuum is created. We need local structures created by the people themselves to carry the development (Swanepoel \& De Beer 2011:76). Research participants, however, argued that often they were not consulted for their input, hence the failure of many public interventions.

Participatory local governance allows citizens to express their concerns regarding matters of public interest. It helps citizens to be heard by public officials and decision makers. Cornwall and Gaventa (2006 in Shafiqul \& Habib 2006:406) agreed, 'As concerns about good governance and state responsiveness grow, questions about the capacity of citizens to engage and make demands on the state come to the fore'. The ability of the local community to voice their concerns is critical to ensure that public officials are responsive to the needs of citizens. However, research participants argued that in most cases their concerns are not attended to by public officials. This has led to the prevalence of violent public protests as local citizens feel let down by the municipality.

\section{The contribution of citizen participation to good local governance in Khayelitsha}

The theme is based on the research question: What contribution does citizen participation make to good local governance in Khayelitsha? Participatory local governance brings citizens closer to local government institutions to foster accountability, transparency and responsiveness of public institutions and officials. Cornwall and Gaventa (2006, in Shafiqul \& Habib 2006:408) asserted that citizen engagement in public affairs has brought citizens in closer contact with institutions and processes of governance. In addition:

[W] here citizens have been able to take up and use the spaces that participatory processes can open up, they have been able to use their agency to demand accountability, transparency and responsiveness from government institutions. (Cornwall \& Gaventa 2006 in Shafiqul 2006:408)

Research participants, however, mentioned that the gap between public officials and the poor kept on widening because of lack of civic education in Khayelitsha.

\section{The benefits derived from collaborative engagement amongst the various stakeholders in local governance in Khayelitsha}

Research participants reiterated the need for strong collaborative engagements amongst the key role players in local governance. Collaboration is critical to ensure that all parties work cooperatively towards common goals for 
the betterment of the local community. Swanepoel (1985 in De Beer \& Swanepoel 2000:76) concurred that through collaboration, 'all the participating organisations, be they governmental or private, have the same goals and objectives that they strive to obtain through interrelated and integrated programmes'. Furthermore, participants argued that effective collaboration should be based on equal power relationships between the poor and public officials.

However, research participants mentioned that collaboration was lacking in Khayelitsha. The local community was not directly involved in public policy formulation and in decision-making processes on matters of public interest. According to Skenjana and Kimemia (in GGLN 2011):

[T] he failure to adequately cater for the broad spectrum of the populace and to appreciate the various societal dynamics has resulted in the exclusion of sizeable segments of the population from the invited spaces. (p. 58)

Participants argued that decisions and policies were made at the top by the government and then imposed on local communities.

\section{Conclusion}

Based on the given findings, one can mention that there is an urgent need for effective public participation in matters of local governance if South African municipalities are to achieve the goals of developmental local government enshrined in the White Paper on Local Government, 1998. The research findings indicated that citizen participation in decision-making processes is an imperative that brings citizens closer to local government. Citizen participation ensures that local citizens' voices and concerns are heard by public officials. Participatory local governance is essential to ensure that public policies, programmes and projects are tailor-made to meet the actual needs of local communities as defined by the communities themselves. Public participation is an imperative for good local governance. Furthermore, the article drew from Arnstein's (1969) typology of citizen participation. According to the model, effective participation takes place under conditions of shared power and equal power relationships between the elite and the poor masses. Without citizen control and influence, public interventions are bound to fail because of lack of local support and ownership. The findings further revealed an urgent need for mechanisms that help to promote and strengthen public participation in local governance.

\section{Recommendations}

Creating mechanisms that help to strengthen participatory local governance for improved service delivery in Khayelitsha is an imperative, if local communities are to fully participate in decision-making processes on matters of local governance. Mechanisms that could be put in place to strengthen participatory local governance in Khayelitsha include the following.

\section{Creation of an enabling environment for citizen participation}

It is imperative for local government officials to create an enabling environment that encourages and promotes public participation in decision-making processes on matters of local governance. An environment based on equal relationships, freedom of expression and association should be created in local communities. The UNCHS-Habitat (2000:11) recommended practical mechanisms such as public hearings, town hall meetings, citizens' forums, city consultation and participatory strategy development. A legal environment that promotes the establishment and functioning of a vibrant civil society capable of participating in urban affairs should also be developed.

\section{Building strong social capital in Khayelitsha}

Based on the writings of Robert Putnam (2000), social capital can be seen as referring to citizens' organisations and social networks based on feelings of trust, community involvement and reciprocity. According to Giddens (2006:673), social capital 'includes useful networks, a sense of mutual obligation and trustworthiness, an understanding of the norms that govern effective behaviour and other social resources that enable people to act effectively'. Building strong social capital entails creating an enabling environment that encourages local citizens to belong to CSOs such as NGOs, CBOs, faith-based organisation (FBOs), labour movements, citizens' forums and clubs. Strong social capital is an imperative that enables local communities to collectively participate in public affairs. Hustedde (2009 in Phillips \& Pittman 2009:22) postulated that 'social capital is often correlated with confidence in publicinstitutions, civic engagement, self-reliance, economic development and overall community well-being and happiness'. Fukuyama (2001:7) saw social capital as important to the efficient functioning of modern economies and as the foundation of stable liberal democracy.

\section{Promoting collaborative engagements}

Collaborative engagements based on equal power relationships are essential to strengthen participatory local governance for improved service delivery in Khayelitsha. There is an urgent need for collaboration amongst the key role players in Khayelitsha - municipal officials (ward councillors), business, the local community and NGOs. Collaboration is critical to ensure sharing of ideas and best practices. Collaborative engagement resonates with Arnstein's (1969) level of 'partnership' on the ladder of citizen partnership. According to Arnstein (1969:221) at the partnership level, citizens and powerholders 'agree to share planning and decision-making responsibilities through such structures as joint policy boards, planning committees and mechanisms for solving impasses'. Collaboration gives power to the previously disadvantaged groups.

\section{Capacitation of the local community}

One of the most popular causes of poor citizen participation in local governance matters is lack of knowledge about their 
rights and responsibilities. Community capacitation, through public workshops and civic education programmes organised by NGOs, is critical to empower local citizens to participate in matters of public interest. Cornwall and Gaventa (2006 in Shafiqul \& Habib 2006:408) concurred that 'in the field of political participation, methods such as popular education on rights and responsibilities, are often aimed towards developing a more informed citizenry who could hold elected representatives accountable'.

\section{Holding regular public meetings}

Holding regular public meetings for the purposes of deliberations, communicating changes to public policies and giving feedback to local communities may also go a long way in strengthening participatory local governance. Local citizens have a constitutional right to receive regular and appropriate information and feedback from public officials. Regular meetings are critical to ensure continued transparency of public institutions. According to Cornwall and Gaventa (2006 in Shafiqul \& Habib 2006:409), public meetings and committees are transformed when user groups and citizen councils are given new powers and responsibilities and when these spaces are effectively used for the exchange of information, views and reasoned argument on policy possibilities.

\section{Building strong ward committees}

Ward committees are critical mechanisms for citizens' participation in local government affairs. Ward committees are used for purposes of deliberations on council budgets and to allow citizens to participate in IDPs. Ward committees as the formal forums for public participation are mainly established in local municipalities to enhance participatory democracy and to serve as advisory bodies to councillors (Skenjana \& Kimemia, in GGLN 2011:58). Participation in municipal IDPs is critical to enable citizens to understand the municipality's development trajectories and plans. It is also important for public institutions and officials to be open for scrutiny to members of the public and the media. This is essential to promote transparency and accountability. The UNCHS-Habitat (2000:11) agreed that participatory local governance is achievable under conditions of open, timely and free debate about urban issues in the media.

\section{Acknowledgements}

We would like to sincerely thank the ward councillors in Khayelitsha's sub-councils 9 and 10 for their participation in the research. Our gratitude also goes to the community members in Khayelitsha who answered the research questions. Finally, we would like to thank Mr Z. Mgwatyu, the Housing and Human Settlement Programme Manager at Development Action Group (DAG) for his contribution in answering the interview questions and giving me an insight into DAG's programmes. This article is partly based on a Masters Dissertation submitted by the corresponding author at the University of Johannesburg. Dissertation Title: The role of NGOs in participatory local governance for improved service delivery in Khayelitsha, under the supervision of
Prof. Nel-Sanders of the UJ School of Public Management and Governance.

\section{Competing interests}

The authors have declared that no competing interests exist.

\section{Authors' contributions}

K.M. and D.N-S. contributed equally to this work.

\section{Ethical considerations}

This article followed all ethical standards for research without direct contact with human or animal subjects.

\section{Funding information}

This research received no specific grant from any funding agency in the public, commercial or not-for-profit sectors.

\section{Data availability}

The authors confirm that the data supporting the findings of this study are available within the article.

\section{Disclaimer}

The views and opinions expressed in this article are those of the author and do not necessarily reflect the official policy or position of any affiliated agency of the author.

\section{References}

André, P., Enserink, B., Connor, D. \& Croal, P., 2006, Public participation international best practice principles, Special Publication Series, No. 4, International Association
for Impact Assessment (IAIA), Fargo, viewed 24 September 2020, from https:// www.researchgate.net/publication/322603480_Public_Participation_ WwW.researchgate.net/publication
International_Best_Practice_Principles.

Arnstein, S.R., 1969, 'A ladder of citizen participation', Journal of the American Planning Association 35(4), 216-224.

Auriacombe, C.J., 2016, 'Towards the construction of unobtrusive research techniques: Critical considerations when conducting a literature analysis', African Journal of Public Affairs 9(4), 1-19.

Babbie, E., 2016, The practice of social research, 14th edn., Cengage Learning, Boston, MA. Babbie, E. \& Mouton, J., 2001, The practice of social research, Oxford University Press Southern Africa (Pty) Ltd., Cape Town.

Cloete, F., 2018, 'Policy agenda setting', in F. Cloete, C. De Coning, H. Wissink \& B. Rabie (eds.), Improving public policy for good governance, 4th edn., p. 143 Van Schaik, Pretoria.

Cooke, B. \& Kothari, U., 2001, Participation: The New Tyranny?, Zed Books, New York, NY.

Cornwall, A. \& Gaventa, J., 2006, 'Participation in governance', in H.A. Shafiqul \& Z. Habib (eds.), International development governance, pp. 403-413, Taylor \& Francis, New York, NY.

Creswell, J.W., 2009, Research design: Qualitative, quantitative, and mixed methods approaches, 3rd edn., Sage Publishing, Thousand Oaks, CA.

Creswell, J.W. \& Creswell, J.D., 2018, Research design: Qualitative, quantitative and mixed methods approaches, 5th edn., Sage, CA.

Department of Cooperative Governance and Traditional Affairs (CoGTA), 1998, White Paper on Local Government, viewed 14 September 2020, from https://www. cogta.gov.za>uploads>2016/06>whitepaper_on_local-Gov_1998.

Fukuyama, F., 2001, 'Social capital, civil society and development', Third World Quarterly 22(1), 7-20. https://doi.org/10.1080/713701144

Giddens, A., 2006, Sociology, 5th edn., Polity Press, Cambridge.

Hillard, V.G. \& Wissink, H.F., 2000, 'Local government and development in South Africa', in F. De Beer \& H. Swanepoel (eds.), Introduction to development studies, 2nd edn., p. 97, Oxford University Press Southern Africa, Cape Town.

Hustedde, R.R., 2009, 'Seven theories for seven community developers', in R. Phillips \& R.H. Pittman (eds.), An introduction to community development, p. 22, Routledge, Abingdon. 
Mchunu, N., Theron, F. \& Mubangizi, B., 2016, 'Developmental local government and good governance - Facilitation from grassroots', in F. Theron \& N. Mchunu (eds.),
Development, change and the change agent: Facilitation at grassroots, 2 nd edn., p. 113, Van Schaik, Pretoria.

Neuman, W.L., 2011, Social research methods: Qualitative and quantitative approaches, 7th edn., Pearson Education, Boston, MA.

Patton, M.Q., 2002, Qualitative research \& evaluation methods, 3rd edn., Sage Publishing, Thousand Oaks, CA.

Ramjee, M. \& Van Donk, M., 2011, 'Introduction: Recognising community voice and dissatisfaction', in Good governance learning network. Recognising community voice and dissatisfaction: A civil society perspective on local governance in South Africa, viewed 21 September 2020, from https://ggln.org.za/media-andpublications/publications/state-of-local-governance/2011.

Republic of South Africa (RSA), 1996, The Constitution of the Republic of South Africa, viewed 21 September 2020, from www.justice.gov.za/legislation/constitution/ SAConstitution-web-eng.pdf.

Republic of South Africa (RSA), 1997, The White Paper on the Transformation of the Public Service [Batho Pele White Paper / WPTPS] of 1997, Government Gazette, vol. 388 , no. 18340 , viewed 21 September 2020, from www.gov.za/sites/default/ files/gcis_document/ 201409/183401.pdf.

Republic of South Africa (RSA), 1998, Local Government: Municipal Structures Act, No. 117 of 1998, Government Gazette, vol. 402, no. 19614, viewed 22 September 2020, from https://www.gov.za>document>local-government-municipal-structure.

Republic of South Africa (RSA), 1999, The Public Finance Management Act, No.1 of 1999, Government Gazette, vol. 405, no. 19814, viewed 27 September 2020, from www.gov.za.

Republic of South Africa (RSA), 2000, Local Government: Municipal Systems Act, No. 32 of 2000, Government Gazette, vol. 425, no. 21776, viewed 22 September 2020, from https://www.gov.za>documents>local-government-municipal-systems-act.
Siddle, A. \& Koelble, T.A., 2012, The failure of decentralisation in South African Local Government: Complexity and unanticipated consequences, UCT Press, Claremont, CA.

Skenjana, N. \& Kimemia, P., 2011, 'Existing mechanisms for public participation at local government level', in Good governance learning network. Recognising community voice and dissatisfaction: A civil society perspective on local governance in South Africa, viewed 21 September 2020, from https://ggln.org.za/ media-and-publications/publications/state-of-local-governance/2011.

Swanepoel, H.J. \& De Beer, F., 2011, Community development: Breaking the cycle of poverty, 5 th edn., Juta, Lansdowne.

Theron, F. \& Mchunu, N., 2014, 'Public participation as a micro-level development strategy: The principles and context for authentic and empowering development' in I. Davids \& F. Theron (eds.), Development, the state and civil society in South Africa, 3rd edn., p. 113, Van Schaik, Pretoria.

United Nations Centre for Human Settlements (UNCHS-Habitat), 2000, 'The global campaign for good urban governance', Environment and Urbanisation 12(1), 197-202. https://doi.org/10.1177/095624780001200114

United Nations Development Programme (UNDP), 2009, Democratic governance reader: A reference for UNDP practitioners, Bureau for Development Policy, New York, NY.

Van der Waldt, G., 2014a, 'Municipal management: An orientation', in G. Van der Waldt (ed.), Municipal management: Serving the people, 2nd edn., p. 53, Juta, Claremont, CA.

Van der Waldt, C., 2014b, 'The statutory and regulatory framework for local government', in G. Van der Waldt (ed.), Municipal management: Serving the people, 2nd edn., Juta, Claremont, CA.

Van der Waldt, G., 2017, UJ internal handbook: Good governance and sustainability in Africa, University of Johannesburg, Johannesburg.

World Bank, 1989, Sub-Saharan Africa: From crisis to sustainable growth: A long-term perspective study, World Bank, Washington, DC.

Yin, R.K., 2012, Applications of case study research, 3rd edn., Sage, CA. 